Original Research

\title{
Rencana Pemisahan Catalonia dari Spanyol Ditinjau dari Prinsip Self-Determination
}

\author{
Mochamad Ardhi Ma'arif ${ }^{1 *}$, Wisnu Aryo Dewanto일 ${ }^{1}$ Muhammad Insan Tarigan ${ }^{1}$ \\ Fakultas Hukum Universitas Surabaya, Raya Kalirungkut, Surabaya - Indonesia 60293 \\ *Corresponding author: ardhimaarif69@gmail.com
}

Abstract-This Study discussed the problem whether the secession of Catalonia from Spain is in accordance with the selfdetermination principle in the International Law. This study used a legal, concept and case approach and concluded as follows: Catalonia was able to separate them selves from the parent nation according to the self-determination principle by making a referendum. This act of making a referendum was a way for the Catalonia society to state their opinion. This condition was in accordance with the self-determination principle in the international law because the right for secession may occur in a certain condition other than the context of decolonization. When a country is retricted by the reigning government in savoring internal self-determination (in obtaining political, economic, social and cultural status), then the country may perform a secession from the parent nation. The requierements of self-determination in the Catalonia and Spain case were political, economic, social and cultural aspects. Afterwards, Catalonia needed full fill the requirements stated in Article 1 of the 1933 Montevideo Convention on the Rights and Duties of States, and they need to get a recognition from another country.

Keywords : secession, referendum, self-determination principle, recognation

\begin{abstract}
Abstrak-Penelitian berjudul rencana pemisahan Catalonia dari Spanyol di tinjau dari prinsip self-determination, dengan membahas permasalahan apakah pemisahan diri Catalonia dari Spanyol sesuai dengan prinsip self-determination dalam hukum internasional. Penelitian ini menggunakan pendekatan undang-undang, konsep dan kasus, sehingga diperoleh suatu kesimpulan bahwa Catalonia bisa memisahkan diri dari Spanyol sesuai dengan prinsip self-determination dengan melakukan referendum. Referendum adalah suatu cara masyarakat Catalonia untuk menyampaikan pendapat. Hal ini sesuai dengan prinsip selfdetermination dalam hukum internasional, karena hak untuk memisahkan diri bisa muncul dalam keadaan khusus, selain dalam konteks dekolonisasi. Ketika suatu bangsa dihalangi haknya oleh pemerintah yang berkuasa dalam menikmati internal selfdetermination (untuk mendapatkan status politik, ekonomi, sosial dan budaya), maka sebagai jalan terakhir yang diperbolehkan dalam hukum internasional adalah upaya melepaskan diri dari negara tersebut. Syarat-syarat self-determination dalam kasus Catalonia dengan Spanyol yang ingin memisahkan diri adalah aspek politik, ekonomi, sosial dan budaya. Setelah itu Catalonia harus sesuai dengan Konvensi Montevideo Tentang Hak dan Tugas Negara Tahun 1933 Pada Pasal 1 yaitu syarat terbentuknya suatu negara, dan terakhir Catalonia harus mendapatkan pengakuan dari sebuah negara.
\end{abstract}

Kata kunci : pemisahan diri, referendum, prinsip self-determination, pengakuan

\section{Pendahuluan}

Catalonia merupakan bagian dari Spanyol. Catalonia adalah salah satu wilayah yang berpenduduk 7,45 juta orang atau 1/5 dari penduduk Spanyol. Catalonia adalah penggerak perekonomian Spanyol, seperti maritim, perdagangan tekstil, finansial, layanan jasa dan industri berteknologi. Catalonia ingin memisahkan diri dari Spanyol, karena krisis ekonomi yang melanda Spanyol dan Catalonia menjadi harapan perekonomian tersebut. Catalonia membuat sebuah referendum yang bertujuan sebagai hak memilih memisahkan diri dari Spanyol atau tetap menjadi bagian Spanyol. Spanyol tidak menyetujui Catalonia memisahkan diri. Referendum Catalonia ini menelan korban dikarenakan Spanyol menangkap orang-orang yang mendukung dalam referendum. Selanjutnya, pemisahan diri yang diinginkan oleh Catalonia akan merugikan Spanyol yang kehilangan 20 persen hasil ekonomi.

Pemisahan diri negara dalam hukum internasional ada prinsip sesuai dengan kebiasaan internasional yang dikenal prinsip self-determination yaitu hak dari suatu masyarakat kolektif tertentu seperti untuk menentukan masa depan politik dan ekonominya sendiri dari suatu bangsa, tunduk pada kewajiban-kewajiban menurut hukum internasional. Hak tersebut hanya dapat digunakan sekali dan tidak dapat diterapkan terhadap bangsa yang telah terorganisasi di dalam bentuk suatu negara yang tidak berada dalam penjajahan dan dominasi asing.

Dalam prinsip ini terdapat dua jenis self-determination. Pertama, (right to selfdetermination) yang merupakan hak yang bersifat sekali dan tidak dapat dipecah untuk membentuk suatu negara atau integrasi atau asosiasi. Kedua, (right of self- determination) yang merupakan hak yang bersumber dan merupakan konsekuensi dari "right to self- 
determination", yaitu hak untuk menentukan bentuk negara (republik atau kerajaan), sistem pemerintahan (presidensiil atau parlementer), sistem ekonomi (centrally planned economy atau market economy) yang semuanya bersifat pengaturan ke dalam atau urusan dalam suatu negara.

Prinsip self-determination ini memiliki pembatasan secara hukum (legal limit) yakni hanya ditujukan pada proses dekolonisasi. Hal ini diberikan terhadap negara-negara penjajahan ketika melakukan dekolonisasi terhadap negara jajahannya sehingga negara tersebut menentukan nasib sendiri. Dekolonisasi merupakan suatu proses membebaskan suatu bangsa dari penjajahan, baik yang ditempuh melalui suatu perjuangan kemerdekaan nasional.

Terbentuknya negara didasarkan pada hak bangsa untuk menentukan nasibnya sendiri, kemudian untuk melaksanakan prinsip ini masyarakat bisa menggunakan haknya melalui referendum atau plebisit. Referendum adalah proses pemungutan suara terhadap seluruh rakyat yang memiliki hak pilih mengenai suatu masalah untuk mengambil keputusan (kamus besar bahasa Indonesia). Referendum memiliki makna sama dengan plebisit (plebiscite) yaitu pemungutan suara rakyat dari suatu wilayah tertentu atau berupa jajak pendapat masyarakat wilayah tertentu. Referendum atau plebisit adalah bentuk penyelesaian suatu sengketa antar dua negara atau lebih tentang kedudukan suatu wilayah tertentu dan bentuk dari terlaksananya prinsip ini. Pada tahun 2000 ada beberapa negara-negara yang melakukan prinsip self-determination ini seperti Australia yang ingin melepaskan diri dari United Kingdom; lalu ada Crimea yang ingin lepas dari Ukraina menggunakan referendum atau plebisit. Sejauh ini Catalonia sudah membuat sebuah referendum bertujuan ingin memisahkan diri dari Spanyol.

Plebisit merupakan peralihan suatu wilayah dengan negara berdaulat yang berhubungan dengan penduduk wilayah tersebut. Prinsip hak penentuan nasib sendiri dimungkinkan untuk masyarakat yang ada di wilayah jajahan dapat menentukannya secara bebas status politiknya. Penentuan nasib sendiri itu dapat menciptakan kemerdekaan dan dapat memutuskan untuk bergabung dengan negara tetangga ataupun bersekutu secara bebas oleh negara yang bersangkutan. Hak penentuan nasib ini sendiri mempunyai fungsi atau peran dalam hubungannya sebagai terbentuknya suatu negara, mempertahankan suatu kedaulatan negara dan sebagai kemerdekaan suatu negara dalam merumuskan syarat-syarat untuk menyelesaikan perselisihan.

Syarat wilayah menjadi wilayah telah diatur dalam pasal 1 konvensi Montevideo 1933 tentang hak dan kewajiban negara adalah ada wilayah, penduduk, pemerintahan dan kemampuan untuk mengadakan hubungan dengan negara lainnya. Self-determinasi ini tidak memenuhi syarat tersebut dapat menimbulkan kekacauan terhadap sistem-sistem kenegaraan dan hanya menyangkut secara eksklusif yang merupakan hak untuk memilih status negara otonom, tetapi juga pilihan untuk berintegrasi dengan negara induk oleh karena itu unsur tambahan dirasakan penting dalam konvensi ini seperti ketentuan konvensi Montevideo 1933 yang berisikan kapasitas suatu negara maka diubah dengan kedaulatan sebagai unsur konstitutif keempat pembentukan negara. Dalam praktek negara dan dalam keputusan pengadilan serta ditetapkan bahwa untuk menjadi negara tidaklah perlu miliki wilayah yang tetap atau memiliki batas-batas negara yang tidak sedang dalam sengketa. Karena dalam keadaan tertentu, suatu negara pun tetap diakui sebagai subjek hukum internasional.

Ada prinsip yang berkaitan dengan self-determinasi yaitu pengakuan atau recognition karena itu syarat untuk menjadi subjek hukum internasional. Pengakuan atau recognition adalah tindakan sepihak suatu negara untuk menerima atau membenarkan akan sesuatu dalam masyarakat internasional. pengakuan pada intinya merupakan tindakan yang bersifat bebas dari negara untuk mengakui eksistensi negara lain. Masih ada beberapa kesulitan mengenai apa yang dinyatakan sebagai penentuan nasib sendiri baik dalam hal artinya 
maupun yang tercakup dalam istilah tersebut. Hak ini adalah suatu hak yang sifatnya mutlak, hak untuk menentukan nasib sendiri berkonotasi kepada kebebasan untuk memilih dari rakyat yang belum merdeka melalui plebisit (plebiscite) atau metode-metode lainnya untuk memastikan kehendak rakyat.

Dalam masalah pengakuan negara baru ini terdapat dua teori yaitu teori konstitutif dan teori deklaratif. Teori konstitutif adalah suatu negara bisa menjadi subjek hukum internasional hanya melalui pengakuan. Hanya dengan pengakuanlah suatu negara baru bisa dapat diterima sebagai anggota masyarakat internasional dan memperoleh statusnya sebagai subyek hukum internasional. Selanjutnya, teori deklaratif yaitu pengakuan hanyalah merupakan penerimaan suatu negara baru oleh negara-negara lainnya. Suatu negara mendapatkan kemampuannya dalam hukum internasional bukan berdasarkan kesepakatan dari negara-negara yang telah ada terlebih dahulu, namun berdasarkan suatu situasi tertentu. Kemampuan tersebut secara hukum ditentukan oleh usaha-usahanya serta keadaan yang nyata dan tidak perlu menunggu diakui negara lain.

\section{METODE}

Metode penelitian yang digunakan adalah penelitian hukum yuridis normatif, yaitu merupakan penelitian yang berdasarkan pada studi pustaka yang meliputi bahan hukum primer dan bahan hukum sekunder yang terdiri atas peraturan perundang-undangan dan literatur. Metode penelitian yang digunakan dalam penulisan ini terdiri dari berbagai cara dan kegiatan yang dilakukan dalam rangka mengumpulkan data-data dan bahan-bahan yang diperlukan untuk melengkapi penyusunan skripsi ini.

Penelitian ini menggunakan metode kepustakaan (Library Research), yaitu penelitian hukum yang dilakukan dengan cara meneliti dan mengadakan penelusuran literatur hukum serta menganalisis bahan hukum sekunder. Tujuannya untuk memperoleh data atau kebenaran yang akurat sesuai dengan peraturan yang berlaku guna mendapatkan kepastian hukum.

Pendekatan masalah yang digunakan untuk menganalisis masalah adalah statute approach dan conceptual approach. Statute approach yaitu menelaah semua undang-undang dan regulasi yang bersangkutan dengan isu hukum yang sedang ditangani. Pendekatan masalah berikutnya yang digunakan adalah conceptual approach, yaitu pendekatan yang beranjak dari pandangan-pandangan dan doktrin-doktrin yang berkembang di dalam ilmu hukum.

\section{HASIL DAN BAHASAN}

Catalonia membuat sebuah referendum yang bertujuan sebagai hak memilih memisahkan diri dari Spanyol atau tetap menjadi bagian Spanyol. Tindakan dari Catalonia membuat referendum sesuai dengan prinsip self-determination dalam hukum internasional. Karena hak untuk memisahkan diri bisa muncul dalam keadaan-keadaan khusus tertentu, selain dalam konteks dekolonisasi. Yaitu ketika suatu bangsa dihalangi haknya oleh pemerintah yang berkuasa dalam menikmati internal self-determination (untuk mendapatkan status politik, ekonomi, sosial dan budaya), maka sebagai jalan terakhir yang diperbolehkan dalam hukum internasional adalah upaya melepaskan diri dari negara tersebut. bermula dari fenomena kelompok-kelompok masyarakat yang menolak atau tidak dapat menerima lagi atas tindakan penguasa di atasnya. Penguasa ini berbentuk pemerintah atau otoritas pemerintahan yang mereka anggap bertentangan dengan kehendak masyarakat.

Hak menentukan nasib sendiri (the right of self-determination) telah menjadi prinsip dasar hukum internasional umum yang diterima dan diakui sebagai suatu norma yang mengikat dalam masyarakat internasional. Prinsip ini membatasi kehendak bebas negara dalam menangani masalah gerakan separatis yang terjadi di wilayahnya dengan tetap 
mengacu pada kaidah hukum internasional yang mengancam validitas setiap persetujuan persetujuan ataupun aturan dan cara-cara yang ditempuh negara yang bertentangan dengan hukum internasional, karena penentuan nasib sendiri diakui oleh masyarakat internasional sebagai HAM yang harus dihormati. Hal ini dapat dilakukan sesuai dengan syarat selfdetermination melalui beberapa aspek yaitu aspek politik, ekonomi, sosial dan kebudayaan tersebut dalam hak penentuan nasib sendiri sendiri saling berhubungan dan saling ketergantungan satu sama lainnya. Saling ketergantungan setiap aspek tersebut dapat dilihat melalui pengakuan penuh dan implementasi dari masing-masing aspek tersebut.

\section{Aspek Politik}

Aspek Politik menunjukkan sebuah pemikiran bahwa termasuk di dalam hak penentuan nasib sendiri adalah kemampuan dari suatu kelompok orang untuk menunjukkan pemikirannya atau pendapatnya, nasib politiknya melalui cara-cara yang demokratis. Definisi penentuan nasib sendiri termasuk kepada hak suatu bangsa yang terorganisir dalam suatu wilayah yang tetap untuk menentukan nasib politiknya dalam cara demokratis, atau hak dari suatu bangsa yang hidup dalam negara yang merdeka dan berdaulat untuk bebas memilih pemerintahannya, untuk mengangkat institusi perwakilan dan untuk secara periodik memilih perwakilan dengan prinsip kebebasan dan kemerdekaan untuk memilih kandidat ataupun partai politik yang ada. Dalam kasus ini Catalonia menunjukkan keinginan mereka untuk melepaskan diri dan bisa menjadi negara sendiri. Peta politik di Catalonia (Catalunya) berbeda dengan Spanyol. Pengaruh partai Partido Popular yang dipimpin oleh Mariano Rajoy yang menjabat sebagai Perdana Menteri Spanyol sangat kecil pengaruhnya di Catalunya dan hanya menduduki urutan nomor empat di antara partai yang lain. Artur Mas sebagai presiden pemerintahan Catalunya yang berasal dari Partai Serikat dan Persatuan (CiU) mengalang kemerdekaan Catalunya sejak tahun 2014. Namun pemerintahan CiU yang minoritas ingin kemerdekaan diperoleh melalui cara legal dan sesuai dengan konstitusi. Upaya melalui hukum ini selalu dihadang pemerintah pusat Spanyol. Karena itulah partai sayap kiri Catalunya, Esquerra Republicana de Catalunya (ERC), ingin cara yang lebih ekstrem, yaitu tetap melakukan referendum kendati ditolak Spanyol, menetapkan kemerdekaan secara unilateral, dan mengancam tidak akan meloloskan undang-undang CiU jika referendum tidak digelar. Hasilnya, 1 Oktober 2017 Catalunya melakukan referendum walau dianggap inkonstitusional oleh Spanyol.

\section{Aspek Ekonomi}

Aspek ekonomi dari hak penentuan nasib sendiri dalam bentuk hak bagi semua bangsa untuk menentukan sistem ekonomi sendiri dalam rezim penerintahan yang berkuasa dengan semangat kemerdekaan dan kedaulatan. Dalam sudut pandang ekonomi, hak tersebut juga termasuk penggunaan secara permanen oleh suatu bangsa kedaulatan atas pemanfaatan sumber daya alam, dan melindungi wilayah mereka dari kegiatan-kegiatan eksploitasi oleh perusahaan multinasional yang dapat merugikan secara ekonomis suku bangsa asli yang mendiami wilayah tersebut. Bagaimanapun juga, penghormatan terhadap prinsip kedaulatan harus tetap dapat memberikan jaminan terhadap investasi asing. Dalam hal ini aspek ekonomi, Catalonia lebih maju daripada ibu kota Spanyol yaitu Madrid. Catalonia adalah jantung industrinya Spanyol, dengan kekuatan maritim terbesar, dan unggul dalam perdagangan barang jadi seperti tekstil. Saat ini, Catalonia berkembang menjadi rumah bagi perusahaanperusahaan finansial, jasa, dan teknologi. Dengan menyumbang 18,8 \% GDP Spanyol, Catalonia adalah wilayah paling kaya di negara itu, lebih kaya dari Madrid. Di saat krisis ekonomi menimpa Spanyol, suara kemerdekaan Catalunya semakin nyaring. Warga Catalunya menganggap kekayaan Barcelona disedot oleh wilayah-wilayah Spanyol lainnya yang lebih miskin. Kemerdekaan Catalonia akan membuat Spanyol kehilangan 20 persen pemasukannya, 
dan memicu perdebatan soal pembagian utang negara sebesar 836 miliar Euro. Hal ekonomi ini adalah salah satu yang membuat Catalonia ingin memisahkan diri dari Spanyol karena merasa dirugikan dan tidak ada timbal balik dari Spanyol untuk Catalonia.

\section{Aspek Sosial}

Aspek sosial mengandung arti bahwa setiap bangsa di dunia mempunyai hak untuk memilih dan menentukan sistem sosial di wilayah mereka berdiam. Aspek ini terutama berkaitan dengan tegaknya keadilan sosial, dan semua bangsa memilikinya. Seperti halnya Catalonia, mereka memiliki hak untuk berpendapat dan melakukan haknya. Catalonia merasakan tindakan yang kurang baik dari Spanyol seperti ketika Spanyol melakukan penyerangan terhadap masyarakat Catalonia saat pengambilan suara untuk melakukan referendum dan mereka sangat menginginkan hak mereka untuk melepaskan diri dilakukan.

\section{Aspek Budaya}

Aspek budaya berhubungan dengan pembentukan adat istiadat dan kebudayaan bangsa masing-masing, yang merupakan elemen sangat penting dari hak penentuan nasib sendiri. Hal tersebut termasuk pengakuan akan hak untuk memperoleh, menikmati dan menurunkan warisan kebudayaan, serta penegasan akan hak bagi semua orang untuk memperoleh pendidikan. Catalonia dengan wilayah Spanyol lainnya tidak sama, kebanyakan wilayah Spanyol menggunakan bahasa dan budaya yang sama, tetapi tidak untuk Catalonia karena wilayah mereka memiliki budaya dan bahasa yang berbeda dengan Spanyol.

Karena empat aspek inilah Catalonia bisa melakukan self-determination karena Catalonia memenuhi semua aspek, yakni ekonomi, budaya, politik dan sosial. Dari referendum yang ada 90\% masyarakat Catalonia ingin melepaskan diri karena wilayah mereka sudah bisa menjadi negara yang berdiri sendiri dengan berbagai macam aspek. Hak untuk memisahkan diri bisa muncul dalam keadaan-keadaan khusus tertentu, selain dalam konteks dekolonisasi, yaitu ketika suatu bangsa dihalangi haknya oleh pemerintah yang berkuasa untuk mendapatkan status politik, ekonomi, sosial dan budaya, maka sebagai jalan terakhir yang diperbolehkan dalam hukum internasional adalah upaya melepaskan diri.

Faktanya terdapat juga bukti bahwa hukum internasional mendukung hak untuk melepaskan diri. Hal ini bisa dilihat dalam praktik hukum internasional terkait lahirnya negara baru dalam beberapa dekade terakhir, yang bisa memberi kesan diakuinya hak untuk melepaskan diri dalam situasi-situasi khusus tertentu. Contohnya adalah kejatuhan Uni Soviet yang kemudian terpecah-pecah menjadi banyak negara dan perpecahan Republik Yugoslavia. Sukses dari klaim untuk melepaskan diri negara-negara baru adalah sebagian besar karena kehendak komunitas internasional untuk memberikan pengakuan terhadap eksistensi negara mereka.

Negara baru yang diciptakan melalui pelepasan diri, diberikan batasan wilayah negara yang telah dipakai secara administratif sebelum kemerdekaan diraih, ketika negara baru tersebut masih merupakan bagian dari negara asal.

Faktor lain untuk melakukan self-determination adalah syarat terbentuknya negara. Karena ada beberapa syarat untuk membentuk suatu negara dan tercantum pada pasal 1 konvensi Montevideo 1933 mengenai hak-hak dan kewajiban- kewajiban negara disebutkan karakteristik yang harus dimiliki oleh suatu negara untuk dapat dikatakan dan diakui sebagai negara. Negara sebagai subjek hukum internasional harus memiliki syarat-syarat sebagai berikut.

\section{Penduduk Tetap}

Penduduk merupakan kumpulan individu-individu yang terdiri atas dua kelamin, tanpa 
memandang suku, bahasa, agama dan kebudayaan yang hidup dalam suatu masyarakat dan yang terkait dalam suatu negara malalui hubungan yuridis dan politik yang diwujudkan dalam suatu kewarganegaraan. Unsur terpenting dalam pengertian ini bahwa kumpulan individu harus terorganisir dengan baik. Oleh karena itu, penduduk yang tidak mendiami suatu wilayah secara tetap dan selalu berpindah-pindah, tidak dapat dikatakan sebagai penduduk atau rakyat.

\section{Wilayah Tertentu}

Penduduk yang berpindah dari satu tempat ke tempat yang lain (nomaden) tidaklah dipandang sebagai negara. Sebagaimana penduduk tetap, tidaklah penting apakah daerah yang didiami secara tetap itu besar atau kecil. Vatikan misalnya mempunyai luas negara yang lebih kecil dari Nauru. Dalam konteks ini, negara-negara tersebut bisa disebut negara-negara kecil atau mini. Oleh karena itu dalam hukum internasional, baik Singapura dengan luas wilayah $218 \mathrm{~km} 2$ maupun China dengan luas wilayah $9.596 .961 \mathrm{~km} 2$ memiliki kedudukan yang sama sebagai subjek hukum internasional.

\section{Pemerintahan yang Berdaulat}

Yang dimaksud dengan pemerintahan yang berdaulat yaitu kekuasaan yang tertinggi yang merdeka dari pengaruh kekuasaan lain di muka bumi. Akan tetapi kekuasaan yang dimiliki oleh suatu negara terbatas pada wilayah negara yang memiliki kekuasaan itu. Maksudnya adalah dalam kedaulatan suatu negara terbatas pada kedaulatan negara lain. Suatu negara harus memiliki pemerintah, baik seseorang atau beberapa orang yang mewakili warganya sebagai badan politik serta hukum di negaranya, dan pertahanan wilayah negaranya. Pemerintah dengan kedaulatan yang dimilikinya merupakan penjamin stabilitas internal dalam negaranya, disamping merupakan penjamin kemampuan melebihi kewajibannya dalam pergaulan internasional. Pemerintah inilah yang mengeluarkan kewajiban-kewajiban dalam rangka mencapai kepentingan nasional negaranya, baik itu di dalamnya dalam rangka mempertahankan integritas negaranya, maupun di luar negaranya melaksanakan politik luar negeri untuk suatu tujuan tertentu.

\section{Kemampuan Untuk Melakukan Hubungan- Hubungan Dengan Negara Lain}

Penggunaan istilah "Capacity to enter into international relation" dalam pasal 1 Konvensi Montevideo memiliki peranan yang sangat penting. Pentingnya eksistensi unsur keempat ini berakibat pada semakin jelasnya perbedaan antara negara dengan unit-unit kecil seperti anggota-anggota federasi atau protektorat yang tidak mengurusi urusan luar negerinya dan tidak mendapat pengakuan dari negara-negara lain sebagai bagian anggota masyarakat internasional.

Syarat terbentuknya sebuah negara adalah sebuah rangkaian untuk suatu wilayah bisa menjadi suatu negara dan Catalonia sebagai wilayah yang ingin memisahkan diri dari Spanyol harus melalui beberapa tahapan untuk mencapai hal tersebut. Tahapan berikutnya adalah adanya pengakuan sebuah negara. Jika Catalonia ingin menjadi sebuah negara, maka harus diakui oleh negara lain.

Tindakan pengakuan dapat dilakukan secara tegas yaitu melalui pernyataan resmi yang berupa nota diplomatik, note verbale, pesan pribadi Kepala Negara atau Menteri Luar Negeri, pernyataan perlemen atau dengan traktat atau secara tidak tegas apabila tindakan ini bisa disimpulkan dari hubungan tertentu antara negara yang mengakui dan negara baru atau pemerintah baru. Cara melakukan pengakuan bukan merupakan hal yang utama, kecuali bahwa tindakan itu secara tegas dapat memperlihatkan kehendak negara yang mengakui. Tidak ada kaidah hukum internasional yang membatasi bentuk cara atau cara melakukan 
pengakuan.

Pengakuan menurut praktik negara modern bukan sekedar mengetahui (cognition) atau lebih daripada suatu pernyataan mengetahui bahwa suatu negara atau pemerintah memenuhi syarat untuk diakui. Hal ini dibuktikan oleh fakta, antara lain bahwa terjadi penundaan sebelum suatu negara atau pemerintah diakui, meskipun status negara atau pemerintah itu tidak perlu diragukan lagi. Tujuan praktis pengakuan adalah diawalinya hubungan resmi dengan negara yang mengakui, hal ini pun perlu diperhatikan. Sekali pengakuan itu diberikan, maka tindakan itu berarti menghilangkan kemungkinan negara yang mengakui untuk mempersoalkan kembali syarat-syarat untuk diakuinya negara atau pemerintah terkait.

\section{SIMPULAN}

Catalonia ingin melepaskan diri dari Spanyol dengan membuat sebuah referendum. Membuat referendum ini adalah suatu cara masyarakat Catalonia untuk menyampaikan suatu pendapat mereka. Hal ini sesuai dengan prinsip self-determination dalam hukum internasional, karena hak untuk memisahkan diri bisa muncul dalam keadaan-keadaan khusus tertentu, selain dalam konteks dekolonisasi. Ketika suatu bangsa dihalangi haknya oleh pemerintah yang berkuasa dalam menikmati internal self-determination (untuk mendapatkan status politik, ekonomi, sosial dan budaya), maka sebagai jalan terakhir yang diperbolehkan dalam hukum internasional adalah upaya melepaskan diri dari negara tersebut.

Syarat-syarat self-determination dalam kasus Catalonia yang ingin memisahkan diri dari Spanyol adalah aspek politik, ekonomi, sosial dan budaya. Setelah itu Catalonia harus sesuai dengan Konvensi Montevideo Tentang Hak dan Tugas Negara Tahun 1933 Pada Pasal 1 yaitu syarat terbentuknya suatu negara, dan terakhir Catalonia harus mendapatkan pengakuan dari sebuah negara.

Pemisahan diri Catalonia dianggap oleh Spanyol tidak sesuai dengan konstitusi dari pemerintahan Spanyol. Pemerintah Spanyol menolak referendum Catalonia karena tidak sesuai dengan syarat dari sebuah negara dan Catalonia adalah wilayah dari Spanyol yang maju di antara wilayah lainnya seperti perekonomian, sumber daya alam dan kemajuan teknologi.

Dalam kasus Catalonia yang ingin melepaskan diri dari Spanyol bisa terlaksana dengan baik tanpa ada korban yang jatuh, karena ini semua adalah sistem demokrasi. Catalonia punya hak untuk melakukan atau mewujudkan mimpinya, karena pada dasarnya suatu hak itu dimiliki oleh semua manusia dan Catalonia beserta masyarakatnya mempunyai itu. Prinsip Selfdetermination bisa dilakukan karena ada beberapa faktor dari sebuah wilayah yang ingin berdiri sendiri. Catalonia membuat referendum sesuai dengan syarat self-determination.

\section{BIBLIOGRAFI}

Adolf, H 1991, Aspek-aspek negara dalam hukum internasional, Rajawali, Jakarta.

Ardhiwisastra, YB 2003, Hukum internasional, PT. ALUMNI, Bandung.

Bossuyt, M 1987, Guide to the "Travaux Prepatories" of the International Convenant on Civil Political Rights. Martinus Nijhoff Publisher.

Franck, T 1992, 'The emerging right to democratic govermance', The American Journal of International Law, 86(1), 46-91

Iskandar, JT 2006, Hukum internasional kontemporer, PT Refika Aditama, Bandung.

Istanto, FS 1994, Hukum internasional, Universitas Atma Jaya Yogyakarta.

Kumbaro, D 2001, The Kosovo crisis in a international law Perspectiv: Self determination, territorial intergrity and the Nato intervention.

Mauna, B 2003, Hukum internasional, pengertian, peranan, dan fungsi dalam era dinamika global, PT. ALUMNI, Bandung. 
Nur, R 2013, Pengaturan self determination dalam hukum internasional.

Rudy, TM 2002, Hukum internasional. PT. Refika Aditama, Bandung.

Perserikatan Bangsa Bangsa 1993, Konvensi Montevideo tentang hak dan tugas negara.

Samekto, A 2009, Negara dalam dimensi hukum internasional. Citra Aditya Bakti, Bandung.

Santoso, A 2017, Oktober 27, Detik News, Retrieved from https://news.detik.com/internasional/d-3703425/catalonia-nyatakan-merdeka-darispanyol

Sefriani 2011, Hukum internasional: Suatu pengantar. Jakarta.

Starke, JG 2006, Pengantar hukum internasional, Edisi kesepuluh, Sinar Grafika, Jakarta. 


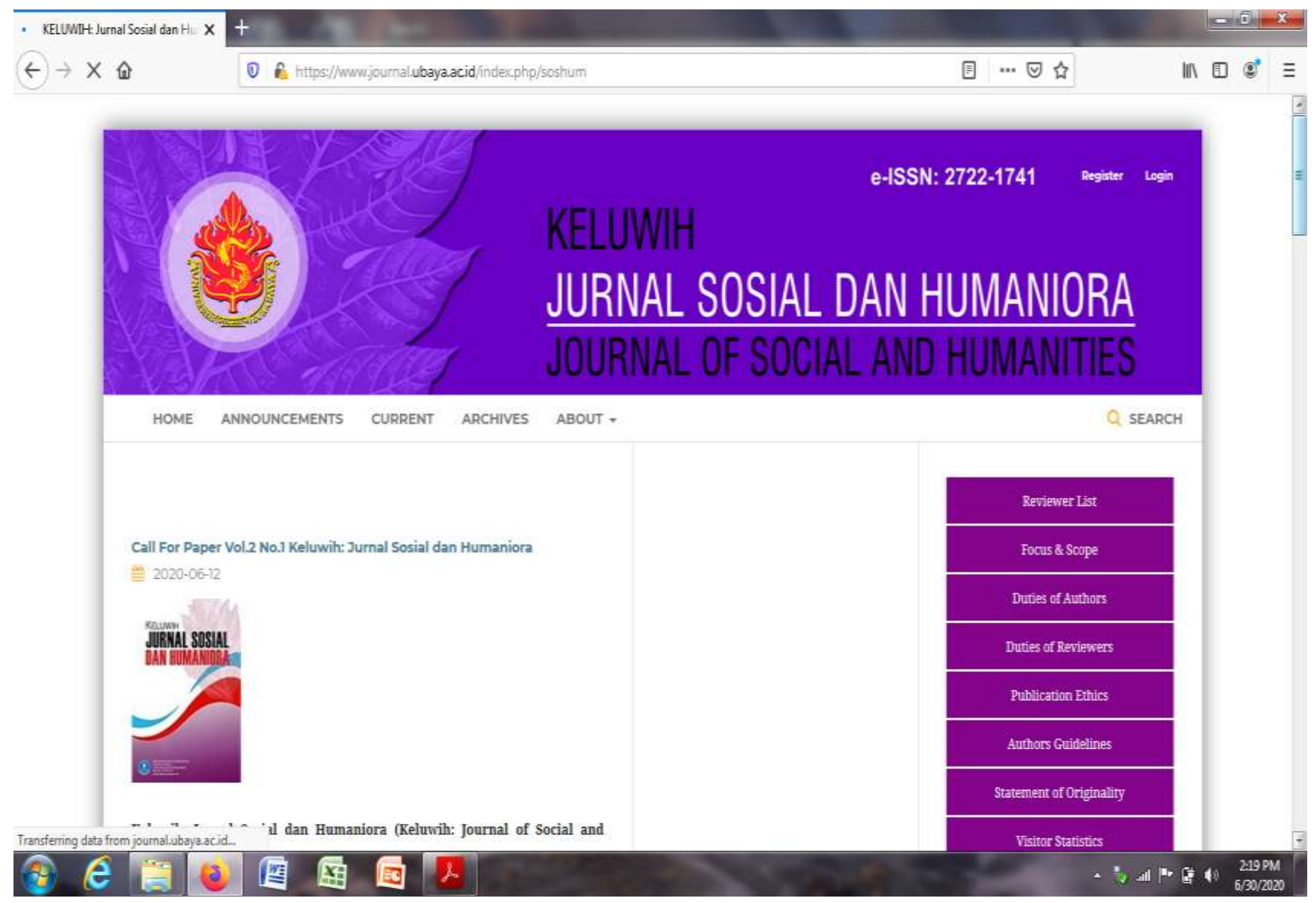




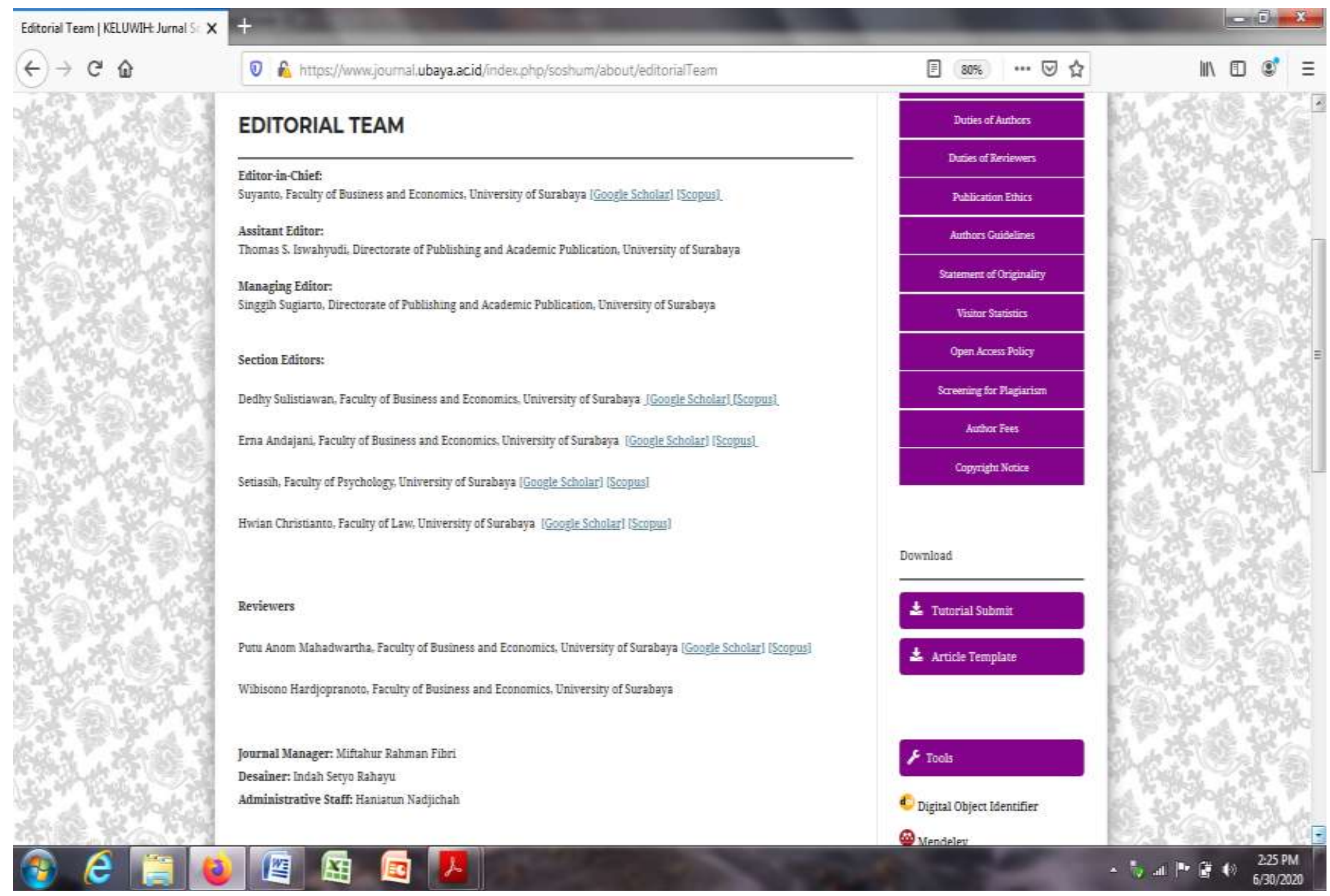




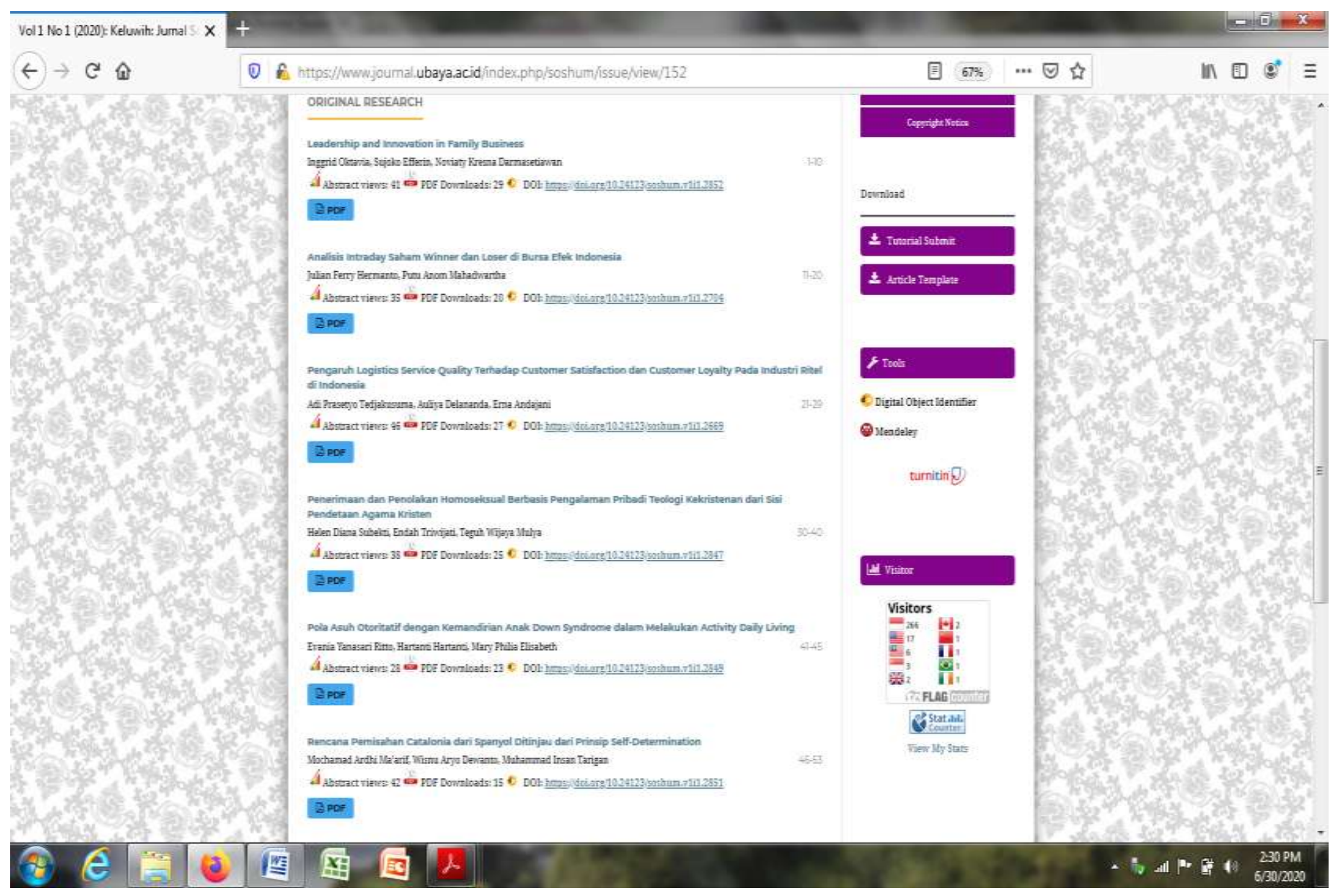




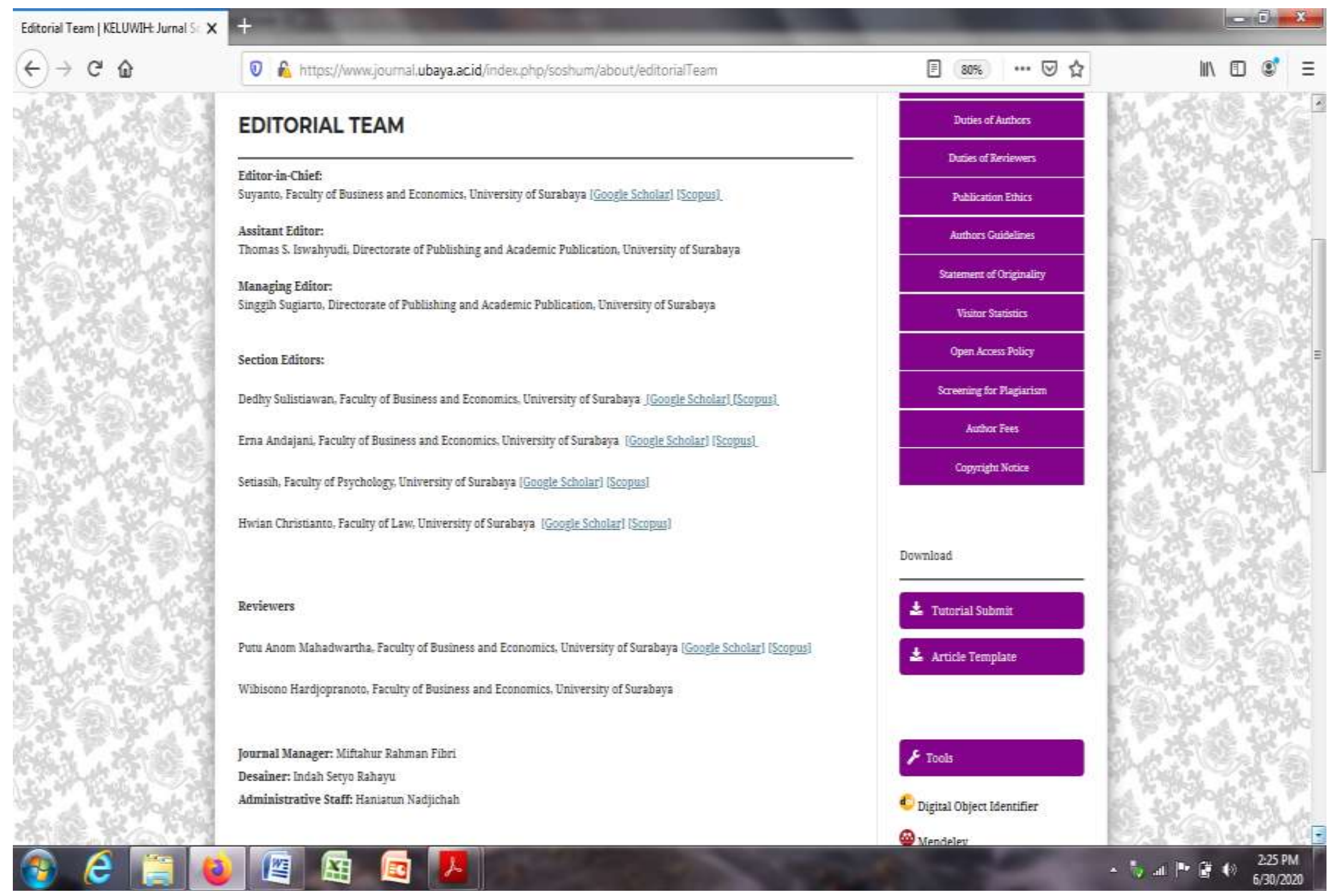

